\title{
Development of a Specific Polymerase Chain Reaction System for the Detection of Rice Orange Leaf Phytoplasma
}

\author{
Zhiyi Wang, ${ }^{1}$ Yingzhi Zhu, ${ }^{2}$ Zhanbiao Li, ${ }^{1}$ Xin Yang, ${ }^{1}$ Tong Zhang, ${ }^{1}$ and Guohui Zhou ${ }^{1, \dagger}$ \\ ${ }^{1}$ Guangdong Province Key Laboratory of Microbial Signals and Disease Control, College of Agriculture, South China Agricul- \\ tural University, Guangzhou, Guangdong 510642, China \\ ${ }^{2}$ College of Marine and Biotechnology, Guangxi University for Nationalities, Nanning, Guangxi 530007, China
}

\begin{abstract}
Rice orange leaf disease (ROLD), caused by rice orange leaf phytoplasma (ROLP), is transmitted by leafhopper vectors Recilia dorsalis and Nephotettix cinticeps. ROLD severely devastates rice production in Asia. Accurate detection of the pathogen is important for disease management. Current nested polymerase chain reaction (nested PCR) method using phytoplasma universal primers is widely used to detect phytoplasmas; however, it has shortcoming of inconvenience and inaccuracy, for it

sequence to amplify house-keeping gene $F t s H-1$ in rice and leafhopper vector samples. This method is simple and rapid, and its sensitivity up to $10 \mathrm{pg} / \mu \mathrm{l}$ of total ROLP DNA. It also minimizes the false positive problem produced by nested PCR. This method was used to survey the geographic distribution of ROLD in southern China from 2016 to 2018. The results showed that the distribution areas and vector carrying rate of ROLD had gradually increased.
\end{abstract} needs two round of PCR reactions and could produce false positive results due to nontarget amplification. In this study, we developed a PCR assay using a set of primers designed based on the ROLP genome
Keywords: rice orange leaf disease, phytoplasma, Recilia dorsalis, Neph otettix cinticeps, phytoplasma specific primer, PCR detection
Rice orange leaf disease (ROLD), caused by rice orange leaf phytoplasma (ROLP), was first discovered in Thailand in 1960s, and then found in India, the Philippines, Malaysia, and other Asian countries (Hibino et al. 1987; Saito et al. 1976; Valarmathi et al. 2013). In China, it mainly occurs in rice-growing areas of Yunnan, Guangxi, Guangdong, and Hainan provinces (Chen et al. 2001; He et al. 2016; Lin et al. 1983; Shen et al. 1983). Disease symptoms include yellow and orange streaks appearing from the leaf apex, followed by leaf orange and scorch and death of whole plants (He et al. 2016; Zhang et al. 1995). By the 1980s, the disease broke out in southern China, causing serious yield losses in rice production (Zhang et al. 1995). Since then, there have been no reports of epidemic outbreaks of this disease. Recently, the disease has reemerged in southern China (He et al. 2016).

ROLP is a member of the 'Candidatus Phytoplasma asteris' (16SrI) group, which comprises a number of related phytoplasmas including onion yellows phytoplasma (OY-M), aster yellows witches'broom phytoplasma (AY-WB), and maize bushy stunt phytoplasma (MBS) (Zhu et al. 2017). Since phytoplasmas cannot be cultured in vitro and are transmitted by insect vectors from plant to plant (Hogenhout et al. 2008), the phytoplasma infection is mainly controlled by reduction of the insect vector population with insecticide applications (Weintraub and Beanland 2006). Thus, it is essential to detect infected plants and insect vectors for disease management (Nejat and Vadamalai 2013). Methods to detect phytoplasmas, such as microscopy technique, were replaced by polymerase chain reaction (PCR) assays in the 1990s (Nejat and Vadamalai 2013). In particular, nested PCR assays using universal primers (P1/P7, along with primer set R16F2nb/R16R2b) based on the conserved $16 \mathrm{~S}$ rRNA gene have been widely adopted for detecting phytoplasmas

${ }^{\dagger}$ Corresponding author: G. H. Zhou; ghzhou@scau.edu.cn

Funding: This research was supported by the National Key R\&D Program of China (2018YFD0200305 and 2016YFD0300700).

The author(s) declare no conflict of interest.

Accepted for publication 3 August 2019.

(c) 2020 The American Phytopathological Society
(Ahrens and Seemüller 1992; Gundersen and Lee 1996; Lee et al. 1993; Zhang et al. 2008). The assay involves two rounds of amplifications by PCR using universal primers, followed by restriction fragment length polymorphism (RFLP) analysis that provides definitive phytoplasma identification (Lee et al. 1993). The disadvantages of nested PCR are that it is time consuming, laborious, and provides nonspecific amplicons (Demeuse et al. 2016; Firrao et al. 2007; Harrison et al. 2002; Lee et al. 2002). Therefore, it is advantages to establish a rapid and accurate PCR system.

Recently, the genome of ROLP was sequenced, and shares $99 \%$ and $98 \%$ similarity to the genome sequences of MBS and OY-M, respectively (Zhu et al. 2017). Genome sequence analysis showed the sequences of three housekeeping genes coding for cell division protein FtsH, thymidylate kinase, and IS3 family transposase vary widely among phytoplasma species (Guevara-Hernandez et al. 2015; Ito and Akiyama 2005; Lee et al. 2011; Mahillon and Chandler 1998; Ostermann et al. 2000; Saraste et al. 1990). In this study, we designed six sets of primers based on the sequences of these three genes for testing in PCR. One set of specific primers was selected to establish an accurate PCR detection method for ROLP in rice and leafhopper vector samples. Compared with traditional nested PCR, results suggested that the established ROLP detection method is more sensitive and time saving.

\section{Materials and Methods}

Phytoplasma-infected samples and DNA extraction. Rice samples affected with ROLD by the presence of orange-colored leaves were collected from Guangdong, Guangxi, and Hainan provinces in China, during the 2015 to 2018 growing seasons. ROLP leafhopper vector and peanut samples infected by peanut witches' broom phytoplasma (PWBP) were collected from Luoding City, Guangdong Province. Wheat samples infected by wheat blue dwarf phytoplasma (WBDP) and sugarcane samples infected by sugarcane white leaf phytoplasma (SWLP) were presented by Dr. Wu Yunfeng (Northwest A\&F University) and Dr. Li Wenfeng (Sugarcane Research Institute of Yunnan Academy of Agricultural Sciences), respectively. Total DNA of all samples was extracted by the cetyl trimethylammonium bromide (CTAB) method (Murray and Thompson 1980).

Designing and screening of specific primers. Cell division protein FtsH, thymidylate kinase (TMK), and IS3 family transposase 
(IS3T) homologous genes sequences of five phytoplasmas (Table 1) were retrieved from the GenBank database of the National Center for Biotechnology Information (NCBI) (https://www.ncbi.nlm.nih.gov/ genbank/). Sequence alignments among the five phytoplasmas were performed by Vector NTI software (Invitrogen, version 11.0) and BLASTn tool (NCBI; https://blast.ncbi.nlm.nih.gov/Blast.cgi, version 1.12). Specific primers were then designed based on the aligned sequences and analyzed for the presence of secondary structures and the possibility of $3^{\prime}$ terminal pairings by using the Primer designing tool of NCBI (https://www.ncbi.nlm.nih.gov/tools/primer-blast/).

The PCR assay using candidate primers was performed using $2 \times$ Taq Master Mix kit (Vazyme, Nanjing, China) in a $25 \mu$ l volume containing $12.5 \mu \mathrm{l}$ of $2 \times$ Taq Master Mix (Dye Plus), $1 \mu l$ of each forward and reverse primer (concentration: $0.4 \mu \mathrm{mol} / \mathrm{liter}$ ), $1 \mu \mathrm{l}$ of template DNA, and $9.5 \mu \mathrm{l}$ of double distilled $\mathrm{H}_{2} \mathrm{O}\left(\mathrm{ddH}_{2} \mathrm{O}\right)$. Products were analyzed by $1.2 \%$ agarose gel electrophoresis. Specific primers were selected by comparing the specificity, amplification efficiency, and primer dimer of candidate primers.

Optimization of detection method and sensitivity determination. To optimize the detection system and evaluate its sensitivity, a series of PCR assays were conducted using the specific primers, and the total DNA of a healthy rice sample and $\mathrm{ddH}_{2} \mathrm{O}$ was used as negative control and blank control, respectively.

Table 1. Information of phytoplasmas used in this study

\begin{tabular}{|c|c|c|c|}
\hline Phytoplasma & Acronym & $\begin{array}{c}\text { GenBank } \\
\text { accession no. }\end{array}$ & $\begin{array}{l}\text { 16S RFLP } \\
\text { groups }\end{array}$ \\
\hline Rice orange leaf phytoplasma & ROLP & MIEP00000000 & $16 \mathrm{SrI}$ \\
\hline Onion yellows phytoplasma & OY-M & AP006628.2 & $16 \mathrm{SrI}$ \\
\hline $\begin{array}{l}\text { Aster yellows witches'-broom } \\
\text { phytoplasma }\end{array}$ & AY-WB & CP000061.1 & $16 \mathrm{SrI}$ \\
\hline $\begin{array}{l}\text { Maize bushy stunt } \\
\text { phytoplasma }\end{array}$ & MBS & СР015149.1 & $16 \mathrm{SrI}$ \\
\hline $\begin{array}{l}\text { Candidatus phytoplasma } \\
\text { australiense }\end{array}$ & CPA & AM422018.1 & 16SrXII \\
\hline
\end{tabular}

Table 2. ROLP infection in rice samples collected in southern China from 2016 to 2018

\begin{tabular}{lccc}
\hline & \multicolumn{3}{c}{ ROLP-positive rates in suspected rice samples } \\
\cline { 2 - 4 } Location & $\mathbf{2 0 1 6}$ & $\mathbf{2 0 1 7}$ & $\mathbf{2 0 1 8}$ \\
\hline Guangdong Province & & & \\
Luoding & $71.21 \%(47 / 66)$ & $40.74 \%(11 / 27)$ & $95.00 \%(19 / 20)$ \\
Leizhou & $100 \%(10 / 10)$ & $86.67(13 / 15)$ & $100 \%(16 / 16)$ \\
Qingyuan & $25.00 \%(1 / 4)$ & $60.00 \%(6 / 10)$ & $70.00 \%(7 / 10)$ \\
Huizhou & $50.00 \%(4 / 8)$ & $100 \%(8 / 8)$ & $77.78 \%(7 / 9)$ \\
Zengcheng & - & $100 \%(6 / 6)$ & $100 \%(12 / 12)$ \\
Fengkai & - & $83.33 \%(5 / 6)$ & $87.50 \%(7 / 8)$ \\
Shanwei & - & - & $100 \%(10 / 10)$ \\
Jiexi & - & - & $100 \%(10 / 10)$ \\
Maoming & - & - & $78.57 \%(11 / 14)$ \\
Enping & - & - & $10.00 \%(1 / 10)$ \\
Guangxi Province & & & \\
Yulin & $50.00 \%(3 / 6)$ & $78.95 \%(30 / 38)$ & $93.75 \%(15 / 16)$ \\
Wuzhou & - & $78.95 \%(15 / 19)$ & $80.00 \%(12 / 15)$ \\
Hezhou & - & $45.90 \%(28 / 61)$ & $76.47 \%(13 / 17)$ \\
Liuzhou & - & $71.42 \%(10 / 14)$ & $73.33 \%(11 / 15)$ \\
Nanning & - & $54.55 \%(6 / 11)$ & $58.33 \%(7 / 12)$ \\
Hechi & - & - & $100 \%(10 / 10)$ \\
Hainan Province & & & \\
Tunchang & - & $9.01 \%(2 / 22)$ & $53.33 \%(8 / 15)$ \\
Timeng & - & $45.45 \%(5 / 11)$ & $58.33 \%(7 / 12)$ \\
Dingan & - & $16.67 \%(1 / 6)$ & $66.67 \%(4 / 6)$ \\
Zhanzhou & - & $100 \%(1 / 1)$ & $60.00 \%(3 / 5)$ \\
\hline
\end{tabular}

a - indicates no ROLD sample found; N/N in parentheses denotes the number of ROLP positive and collected samples, respectively.
Evaluation of primer specificity. To evaluate the specificity of the new method, the specific PCR and nested PCR assays were compared by using the specific primers and 16S rDNA universal primers P1/P7 (5'-AAGAGTTTGATCCTGGCTCAGGATT-3'/5'-CGTCCTTC ATCGGCTCTT-3', for the first round) and R16F2nb/R16R2b (5'GAAACGACTGCTAAGACTGG-3'/5'-TGACGGGCGGTGTGTACA AACCCCG-3', for the second round), respectively (Gundersen and Lee 1996; He et al. 2016; Lee et al. 1993). Total DNA extracted from samples infected with four phytoplasmas (ROLP, WBDP, SWLP, and PWBP), rice plant, and leafhopper vector samples were compared. DNA fragments of expected sizes generated by PCR were purified using a DNA purification kit (Axygen AP-GX-50, Beijing, China), and sequenced by Sangon Biotechnology. The phytoplasma origins of the amplicons were confirmed by BLASTn searching.

Field sample analyses. From 2016 to 2018 , ROLD was surveyed based on the characteristic symptom of orange-colored leaves in Guangdong, Guangxi, and Hainan provinces in southern China. The main rice-growing areas were selected and investigated in each province (Table 2). At least 10 to 30 rice fields were surveyed in each rice-growing area. Rice plants suspected of being affected with ROLD by the presence of orange-colored leaves were collected and detected for ROLP by using the established PCR method.

Leafhopper samples were collected by an insect sweep net $(0.4 \mathrm{~m}$ in diameter) in Luoding City of Guangdong Province. The lower edge of the net was put on the upper third to half of the rice plants and swept back and forth above five clumps of rice plants. At least five clumps in each field and 10 fields were investigated. Two leafhopper vectors were recorded, and the leafhoppers were used for ROLP detection by using the established PCR method.

Table 3. Nucleotide sequence similarities of selected phytoplasmas to ROLP in four candidate genes used for ROLP-specific primer design

\begin{tabular}{lllll}
\hline Genes & OY-M & AY-WB & MBS & CPA \\
\hline Fts $H-1$ & $75 \%$ & $68 \%$ & $74 \%$ & $57.4 \%$ \\
Fts $H-2$ & $72 \%$ & $68 \%$ & $99 \%$ & $33.9 \%$ \\
TMK -1 & $37.2 \%$ & $29.4 \%$ & $33.4 \%$ & $79 \%$ \\
IS 3 T -1 & $92 \%$ & $79 \%$ & $77 \%$ & $88 \%$ \\
\hline
\end{tabular}

Table 4. ROLP candidate-specific detection primers and their main characteristics

\begin{tabular}{|c|c|c|c|c|}
\hline Primers & Sequence $\left(5^{\prime}-3^{\prime}\right)$ & $\mathbf{T m}$ & $\begin{array}{l}\text { Target } \\
\text { genes }\end{array}$ & $\begin{array}{c}\text { Amplicon } \\
\text { size (bp) }\end{array}$ \\
\hline $1355-\mathrm{CF}$ & $\begin{array}{l}\text { GCAAAAGCACTT } \\
\text { GCAGGAGAG }\end{array}$ & $52^{\circ} \mathrm{C}$ & Fts $H-1$ & 368 \\
\hline $1355-\mathrm{CR}$ & $\begin{array}{l}\text { GCTTGTCTTG } \\
\text { CTTTTATGTCGG }\end{array}$ & & & \\
\hline 89-CF & $\begin{array}{l}\text { CCTTTTTAT } \\
\text { GCTGTTTCTGGTTC }\end{array}$ & $50^{\circ} \mathrm{C}$ & Fts $H-2$ & 456 \\
\hline 89-CR & $\begin{array}{l}\text { CTTCATTAAGA } \\
\text { ACAGCTTCCAG }\end{array}$ & & & \\
\hline 89F1 & $\begin{array}{l}\text { GTGCCTTT } \\
\text { TTATGCTGTTTCTGG }\end{array}$ & $50^{\circ} \mathrm{C}$ & Fts $H-2$ & 427 \\
\hline 89R1 & $\begin{array}{l}\text { CTCATTCCAGGTGTCA } \\
\text { TTTTAGC }\end{array}$ & & & \\
\hline 969-TF & $\begin{array}{l}\text { ATTTATGGT } \\
\text { GGCTCCTTTATGG }\end{array}$ & $50^{\circ} \mathrm{C}$ & $T M K-1$ & 425 \\
\hline 969-TR & $\begin{array}{l}\text { ACTTCAGTTTTGTTA } \\
\text { CTTGGGG }\end{array}$ & & & \\
\hline $969 \mathrm{~F} 2$ & $\begin{array}{l}\text { TTTAATTGGGGGGGTA } \\
\text { TTTATGG }\end{array}$ & $50^{\circ} \mathrm{C}$ & $T M K-1$ & 468 \\
\hline 969R2 & $\begin{array}{l}\text { TTCTTCGTATAAAA } \\
\text { AATATTCTTCTTTTAC }\end{array}$ & & & \\
\hline $969 \mathrm{~F} 1$ & $\begin{array}{l}\text { GATTATTACAAAAT } \\
\text { ATGATTTCTCACATTC }\end{array}$ & $50^{\circ} \mathrm{C}$ & $I S 3 T-1$ & 799 \\
\hline 969R1 & $\begin{array}{l}\text { TTGGAATAAAA } \\
\text { AGGGATGTTGGTTG }\end{array}$ & & & \\
\hline
\end{tabular}




\begin{tabular}{|c|c|}
\hline ROL & IG \\
\hline OY-M & TIGCAAAAG--CTCTIGCAGGAGAAGCAGGAGIACCAT-TITATGCAGTATCTGGTICTGAATTTGTAGAAAGATATGTAGG \\
\hline AY-WB & TTGCAAAAG--CATTAGCTAATGAGGCAAAAGTCCCTT-TTTATGCTGTATCIGGTICIGAATTTGICGAAATTIATGTAGG \\
\hline MBS & TTTAAATAATTCTCTIACACGAGAAGCCCCAATTCCTACATTATCTTTCTACAAATTCAGAACCAGATACTGCATAAAATGG \\
\hline CPA & AATICCCTI-TTTATTTCTITTCTGGTTCIGAATTTGTTGAAATGTATGTAGG \\
\hline
\end{tabular}

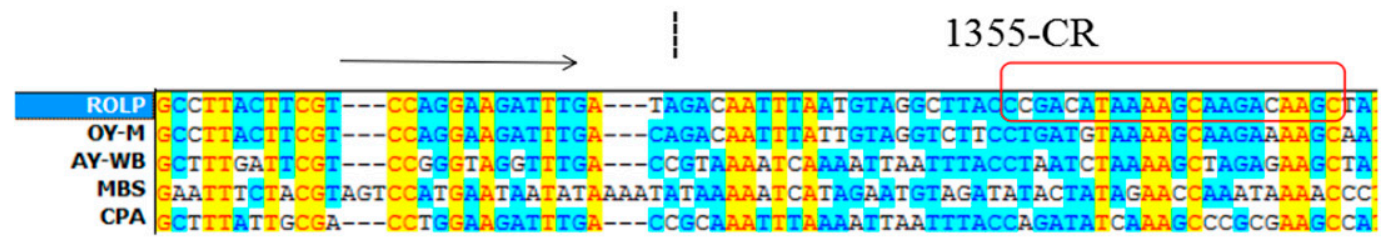

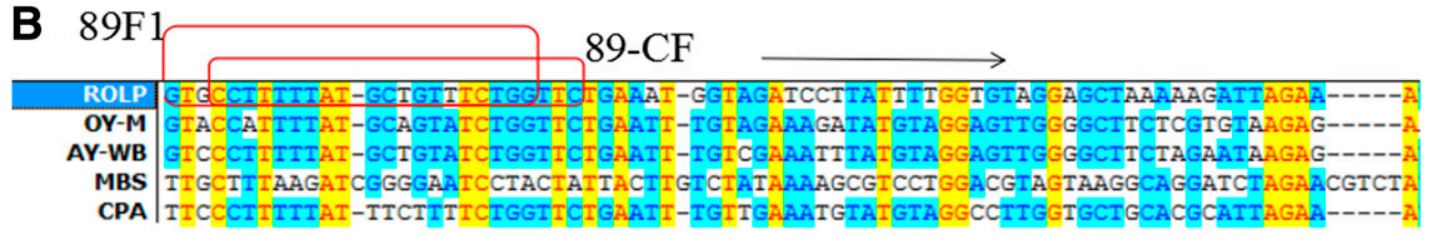

CPA ITCCCTITTIAT-ITCTITICTGGTICTGAATI-IGITGAAATGTATGTAGGCCTIGGTGCTGCACGCATTAGAA-----A

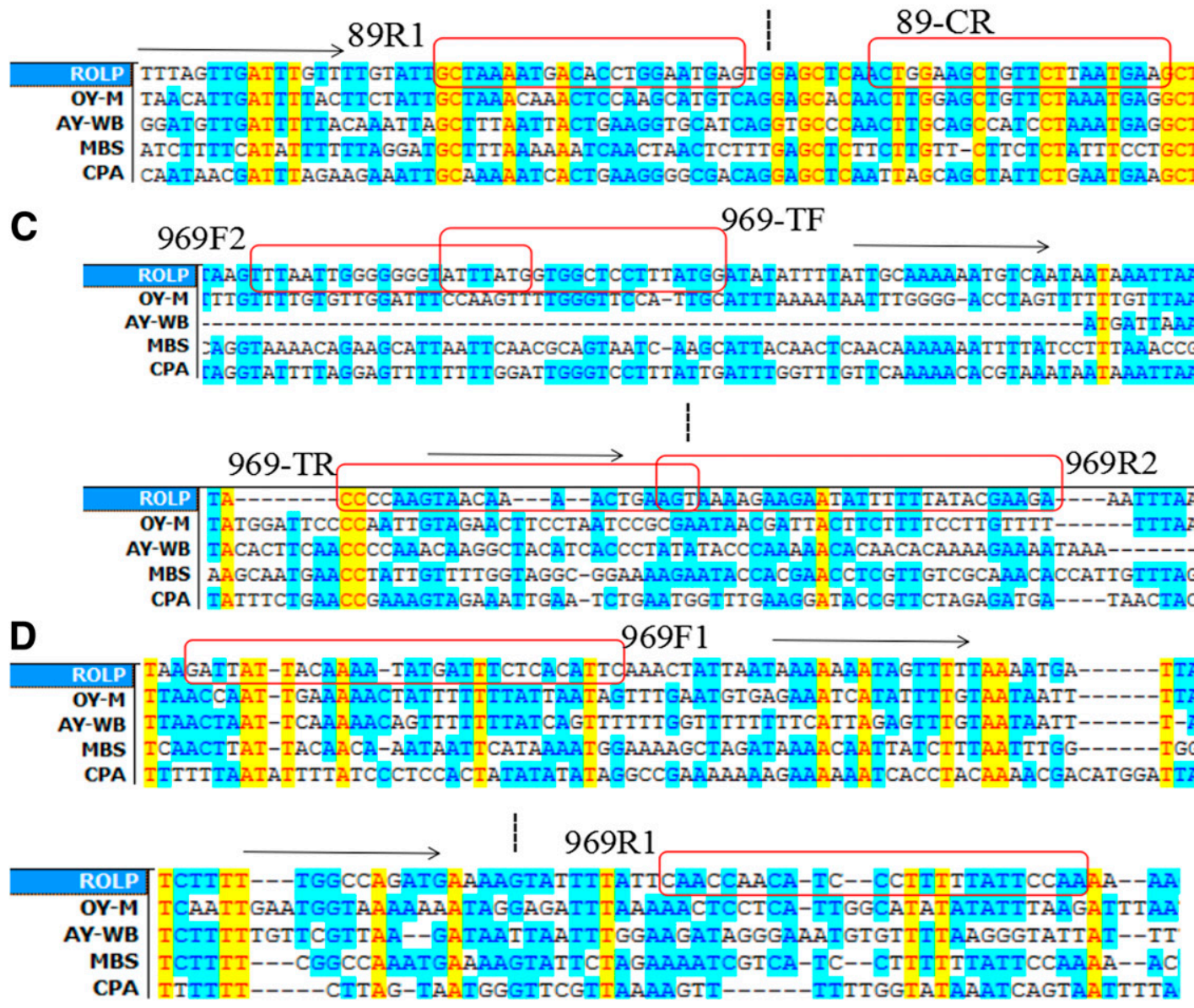

Fig. 1. Schematic diagram of candidate-specific primer design for ROLP detection based on housekeeping genes FtsH-1 (A), FtsH-2 (B), TMK-1 (C), and IS3T-1 (D). A-D is a partial alignment map of the housekeeping gene in ROLP and the homologous gene in the other four phytoplasmas. The positions of six pairs of primers are indicated by red frames. In the sequence, the yellow (lighter) base indicates that it is identical in all phytoplasmas, the blue (darker) base indicates that it is identical in some phytoplasmas; and the arrow indicates the direction of the $5^{\prime}-3^{\prime}$ sequence.
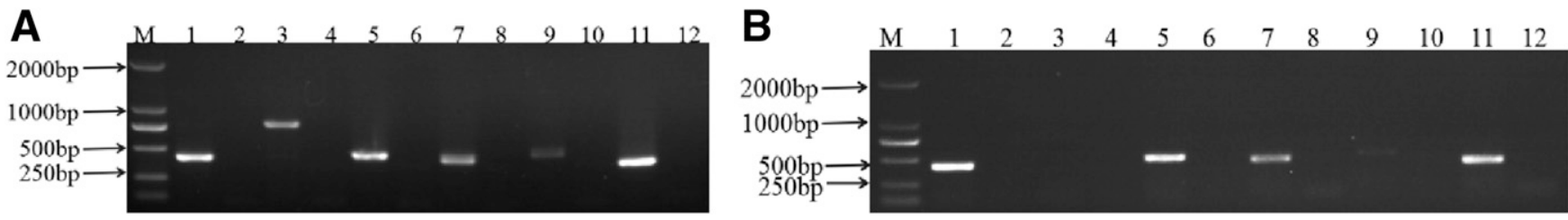

Fig. 2. Results of PCR using six pairs of candidate ROLP-specific primers for the detection of ROLP in rice (A) and leafhopper (B) samples. The odd number of lanes are ROLPpositive samples, and the even number of lanes are ROLP-negative samples. Lane M: marker DL2000; lanes 1-2: primers 89F1/R1; lanes 3-4: primers 969F1/R1; lanes 5-6: primers 89CF/CR; lanes 7-8: primers 969-TF/TR; lanes 9-10: primers 969F2/R2; lanes 11-12: primers $1355 \mathrm{CF/CR}$. 
The detection results were used to analyze the geographic distribution of ROLD and ROLP-carrying rate of the leafhopper vector.

\section{Results}

Design and screening of specific primers. Initial ROLP genome sequence analysis revealed that single-copy genes of FtsH, TMK, and IS3T played important functions and were conserved for ROLP (Ito and Akiyama 2005; Langer 2000; Lee et al. 2011; Mahillon and Chandler 1998; Ostermann et al. 2000; Saraste et al. 1990). Pairwise comparisons showed that the four genes (FtsH-1, FtsH-2, TMK-1, and $I S 3 T-1$ ) shared 33.4 to $99.0 \%$ sequence similarities with homologous genes of the other four phytoplasmas (Table 3), and they were selected as targets for phytoplasma-specific detection. Six sets of ROLP-specific primers were designed and tested (Table 4, Fig. 1).

All of the candidate-specific primers were separately used to amplify the total DNA of healthy and ROLP-infected rice plants as well as ROLP-free and ROLP-infected leafhopper vectors. The amplicons are shown in Figure 2. Sequenced results confirmed the correct gene selected. Primer sets $89 \mathrm{~F} 1 / \mathrm{R} 1$ and $1355 \mathrm{CF} / \mathrm{CR}$ amplified a single product of predicted size and had the best amplification efficiency.

Primers $89 \mathrm{~F} 1 / \mathrm{R} 2$ and $1355 \mathrm{CF} / \mathrm{CR}$ were used to test more samples. Results (Fig. 3) revealed that amplicons by primers 1355CF/CR (Fig. $3 \mathrm{~B}$ and $\mathrm{D}$ ) had fewer primer dimers, indicating that they are more suitable for ROLP detection.

Optimization of PCR detection method and analysis of assay sensitivity. Optimal primer concentrations were determined to be in the range of 0.16 to $0.48 \mu \mathrm{mol} / \mathrm{liter}$. Result revealed that varying the concentrations of primers affected the amplification efficiencies. Higher primer concentrations increased amplification

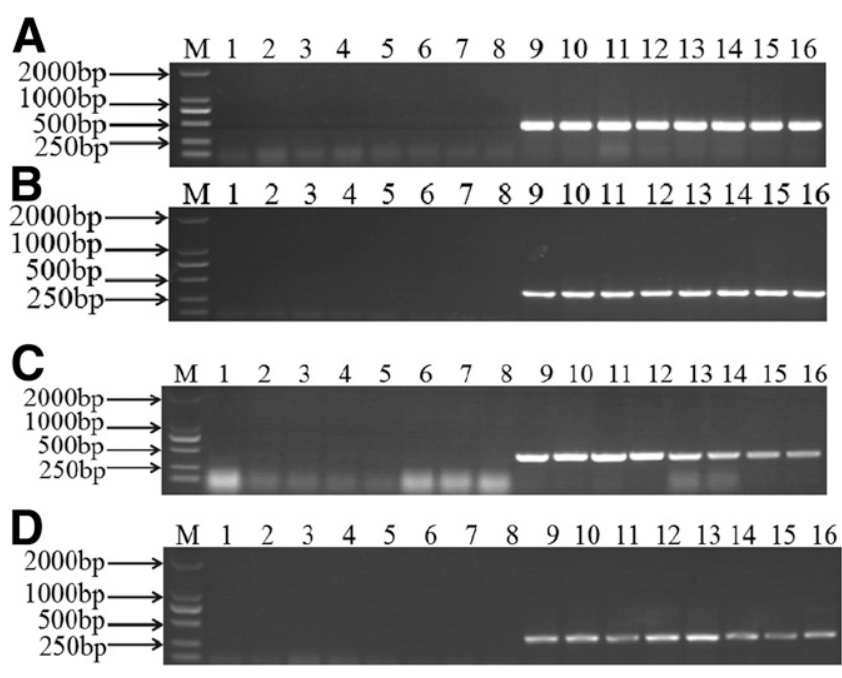

Fig. 3. Results of $P C R$ using candidate ROLP-specific primers $89 F 1 / R 1(A, C)$ and 1355CF/CR (B, D) for samples of rice (A, B) and leafhopper (C, D). Lane M: marker DL2000; lanes 1-8: negative samples; lanes 9-16: positive samples. efficiencies, but when the primer concentration reached $0.4 \mu \mathrm{mol} /$ liter, the PCR efficiency no longer increased (Fig. 4A). To ensure the amplification efficiency, the ROLP-specific primer concentration was set up to $0.4 \mu \mathrm{mol} / \mathrm{liter}$.

A series of annealing temperatures $\left(50\right.$ to $\left.58^{\circ} \mathrm{C}\right)$ were tested in PCR, but the annealing temperature had little effect on the amplification efficiencies. To ensure the specificity of the amplification products, $58^{\circ} \mathrm{C}$ was selected as the annealing temperature for subsequent PCR amplifications. The final PCR program was as follows: $94^{\circ} \mathrm{C}$ for $3 \mathrm{~min}$; 35 cycles of $94^{\circ} \mathrm{C}$ for $30 \mathrm{~s}, 58^{\circ} \mathrm{C}$ for $30 \mathrm{~s}$, and $72^{\circ} \mathrm{C}$ for $60 \mathrm{~s}$; followed by $72^{\circ} \mathrm{C}$ for $10 \mathrm{~min}$.

To analyze the sensitivity of the optimized PCR, 10-fold dilution series $\left(10^{0}\right.$ to $\left.10^{-5}\right)$ of the total DNA of ROLP-infected rice plant samples with an initial concentration of $1,007 \mathrm{ng} / \mu \mathrm{l}$ were used as templates. Results (Fig. 5) revealed that there was no amplification after the $10^{-4}$ dilution, which means the method can detect at least $100 \mathrm{pg} / \mu \mathrm{l}$ of total DNA of ROLP-infected rice samples.

Primer specificities. Total DNA of plants infected with the four phytoplasmas (WBDP, PWBP, SWLP, and ROLP) were tested by PCR using ROLP-specific primers 1355CF/CR and nested PCR using primers $\mathrm{P} 1 / \mathrm{P} 7$ followed by amplification with primers $\mathrm{R} 16 \mathrm{~F} 2 \mathrm{n} /$ R16R2 (Gundersen and Lee 1996; He et al. 2016; Lee et al. 1993). Results (Fig. 6) revealed that the nested PCR could detect all four phytoplasmas, while PCR using ROLP-specific primers $1355 \mathrm{CF} /$ CR specifically detected ROLP.

Both nested PCR and 1355CF/CR PCR detection assays were separately used to test 100 samples each of rice plants and leafhopper vectors. Representative results are shown in Figure 7. Two percent

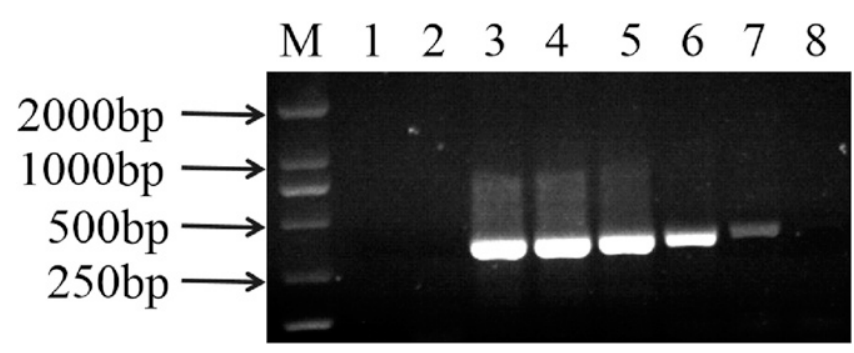

Fig. 5. Results of ROLP-specific PCR with different template concentrations. Lane M: marker DL2000; lane 1: $\mathrm{ddH}_{2} \mathrm{O}$ as template; lane 2: healthy rice; lanes 3-8: ROLPinfected rice leaf total DNA extract dilution $10^{0}-10^{-5}$, respectively.
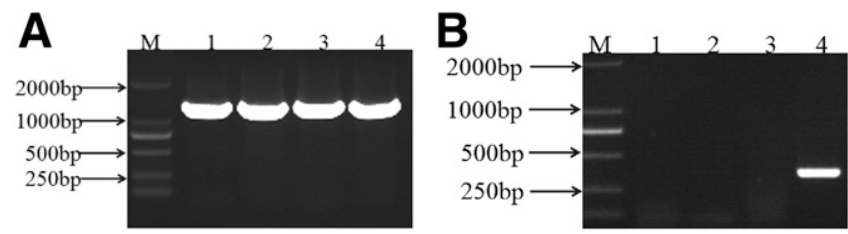

Fig. 6. Results of four phytoplasmas by phytoplasma universal nested PCR $(\mathbf{A})$ and ROLP-specific PCR (B). Lane M: marker DL2000; lanes 1-4: PWBP, WBDP, SWLP, and ROLP, respectively.
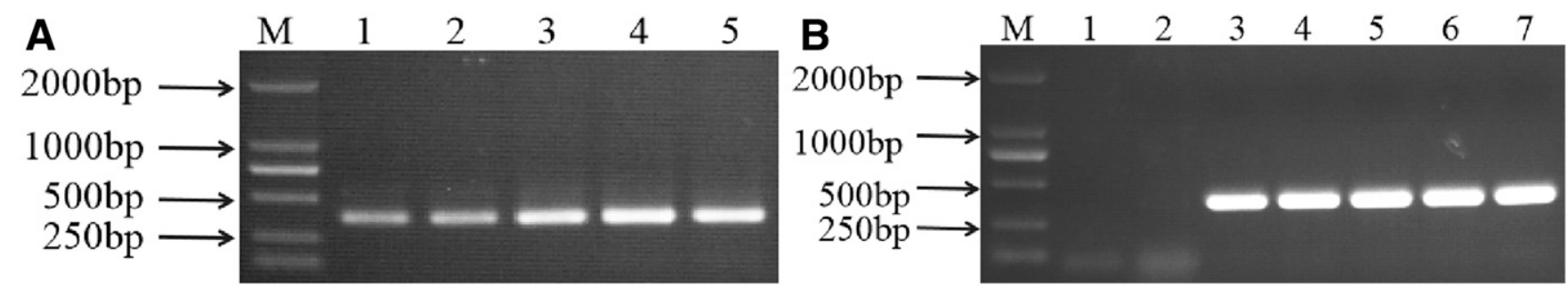

Fig. 4. Results of ROLP-specific PCR using primers $1355 \mathrm{CF} / \mathrm{CR}$ with different primer concentrations (A) and annealing temperatures (B). Lane M: marker DL2000; lanes A1-5: primer concentrations $0.16,0.24,0.32,0.4,0.48 \mu \mathrm{mol} /$ liter, respectively; lane $\mathrm{B} 1$ : $\mathrm{ddH}_{2} \mathrm{O}$ as template; lane $\mathrm{B} 2$ : healthy rice; lanes $\mathrm{B} 3-7$ : annealing temperature $50,52,54,56$, $58^{\circ} \mathrm{C}$, respectively. Total DNA extraction from ROLP-infected rice as template for all reactions. 
of rice and $23 \%$ leafhopper vector samples were positive only in the nested PCR detection method. All the amplicons were sequenced and confirmed by BLASTn searching; results revealed that if samples tested positive by both methods, the amplicons of the nested PCR

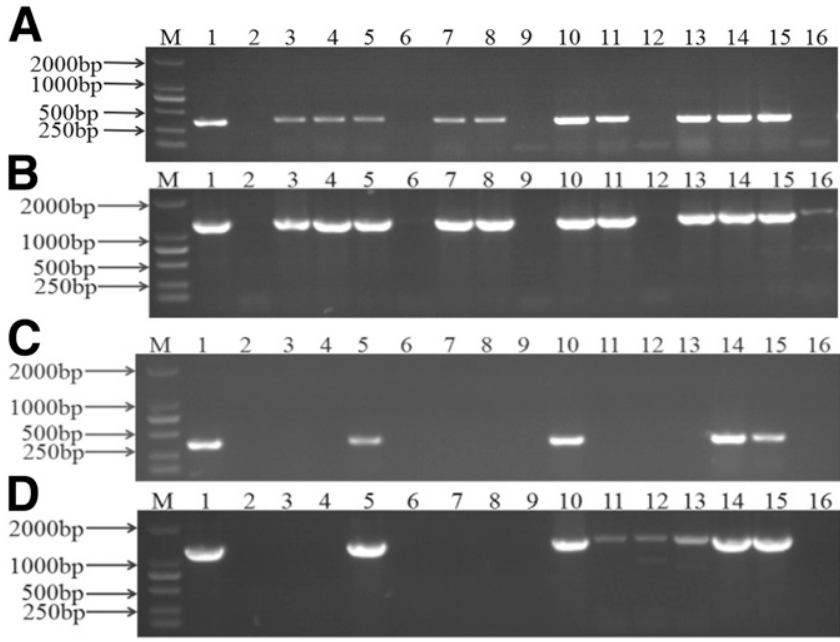

Fig. 7. Detection results of rice $(A, B)$ and leafhopper $(C, D)$ samples by ROLP-specific PCR based on FtsH-1 (A, C) and nested PCR based on 16S rDNA (B, D). Lane M: marker DL2000; lane 1: ROLP-infected rice (A, B) and leafhopper (C, D); lane 2: ROLP-free rice (A, B) and leafhoppers (C, D); lanes 3-16: rice (A, B) and leafhopper (C, D) samples. Lane 16 in $\mathbf{A}$ and $\mathbf{B}$ shows the rice sample that was negative in ROLP-specific PCR (A) and positive in nested-PCR (B). The amplicon sequence of the nested PCR product had no similarity to ROLP. Lanes 11-13 in C and $\mathbf{D}$ show the leafhopper samples that were negative in ROLP-specific PCR (C) and positive in nested PCR (D). The amplicon sequences of the nested PCR had no similarity to ROLP. shared $100 \%$ similarity with the ROLP 16 S ribosomal RNA gene partial sequence (KR061356). However, if samples tested positive only in the nested PCR detection system, amplicons had no similarity with ROLP. Instead, they shared 99.5 to $100 \%$ similarities with multiple Bacillus strains (e.g., strain B1_54, strainE2_5 16) 16S ribosomal RNA gene (e.g., accession nos. MK249953.1, MK249897.1) (results not shown). This indicated the false positive problem in using nested PCR. The new method in this study is more reliable and accurate.

Investigation and detection of ROLP in South China. To investigate the current distributions and incidences of ROLP in the rice fields of southern China, from 2016 to 2018, potentially infected rice and leafhopper samples were collected and analyzed.

The field survey in southern China revealed that, in 2016, rice plants infected with ROLP were found in four rice-growing areas in Guangdong Province and one in Guangxi Province, but no rice plants infected with ROLP were found in three rice-growing areas surveyed in Hainan Province; in 2017, plants infected with ROLP were found in six rice-growing areas in Guangdong Province, five in Guangxi Province, and four in Hainan Province. The investigation in 2018 further confirmed this conclusion (Table 2). Compared with the report in 2015 (He et al. 2016), the area of the disease significantly expanded year by year (Fig. 8).

PCR detection of the leafhopper vectors revealed that in Luoding City of Guangdong Province in 2016 to 2018, the ROLP carrying rates of Nephotettix cincticeps were $18.0 \%$ (9/50), $44.4 \%$ $(16 / 36)$, and $48.0 \%(24 / 50)$, respectively. The ROLP carrier rates of Recilia dorsalis were 15.8\% (6/38), 18.8\% (6/32), and $51.7 \%$ $(31 / 60)$, respectively. This revealed that the ROLP carrying rates of the two leafhopper vectors also increased year by year.

\section{Discussion}

Current nested PCR using universal primers is widely used in phytoplasma detection. However, the target $16 \mathrm{~S}$ ribosomal RNA gene is highly conserved among various species of bacteria, so the universal

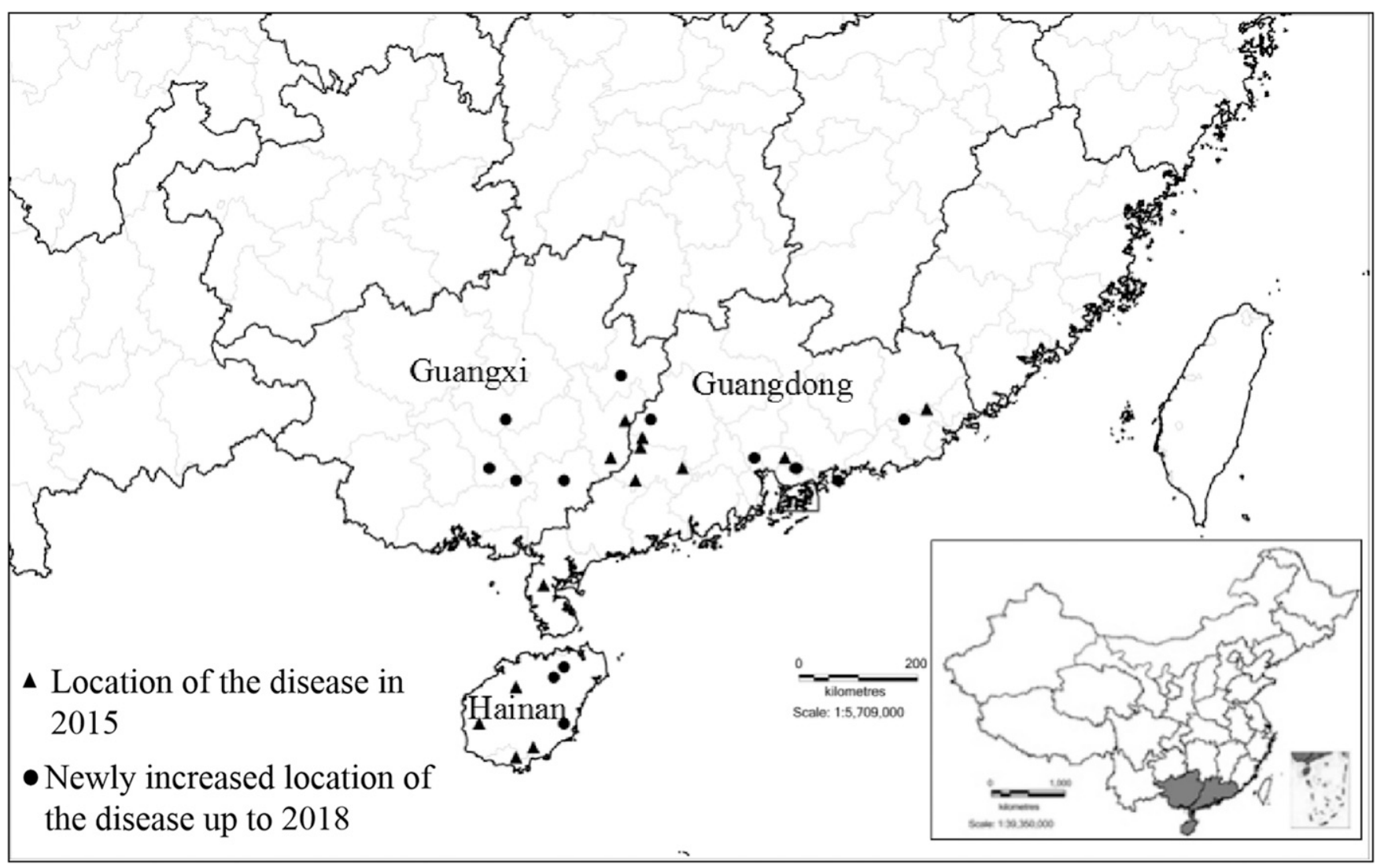

Fig. 8. The geographic distribution of ROLD in South China during 2015-2018. 
primers sometimes amplify nontarget bacterial species (Christensen et al. 2004; Demeuse et al. 2016; Harrison et al. 2002; Lee et al. 2002). In this study, we demonstrated that nontarget Bacillus species were amplified from rice and leafhopper vector samples, causing a false positive problem (Fig. 7). Therefore, it is necessary to establish a more reliable method for the detection of ROLP.

The use of essential genes for species level identification and detection has been shown to be effective. According to the genome sequence of OY-M in the 16SrI group, Kakizawa and Kamagata (2014) developed a multiplex PCR system to amplify several pathogen genes. They designed 36 primers that targeted 18 growth-essential genes such as tuf $\mathrm{B}$, groEL, and $\sec \mathrm{Y}$; nine genes can be simultaneously amplified in a single PCR. The multiplex PCR was applied to DNA from 10 strains belonging to the 16SrI group, and different amplification patterns were obtained. Similarly, Zheng et al. (2016) established a specific PCR assay for ' $\mathrm{Can}$ didatus Liberibacter asiaticus' strains based on the growth-related gene $n r d \mathrm{~B}$. In this study, a ROLP-specific PCR detection method based on housekeeping gene FtsH-1 was established. The method is more reliable for ROLP detection and can provide reference for the development of other phytoplasma-specific detection methods in the future.

Several methods of phytoplasma detection have been developed thus far, including nested PCR with universal primers, PCR with phytoplasma-specific primers, real-time quantitative PCR (RTqPCR) (Demeuse et al. 2016), and loop-mediated isothermal amplification (LAMP) method (Obura et al. 2011). Yet the accuracy and efficiency of these published methods have varied. The sensitivity of nested PCR with universal primers is up to $3 \mathrm{pg} / \mu$ l of phytoplasma DNA (Demeuse et al. 2016), but it needs two rounds of reaction, which is time consuming. The sensitivity of RT-qPCR has been increased 100 times $(0.03 \mathrm{pg} / \mu \mathrm{l})$ over nested PCR and the operation process is simpler (Demeuse et al. 2016), but it needs specific and expensive equipment. Meanwhile, LAMP can detect $0.357 \mathrm{pg} / \mu \mathrm{l}$ of phytoplasma DNA (Obura et al. 2011), but it is susceptible to sample contamination during the operation. In this study, a PCR method for the easily handled, timesaving, low-cost, specific, and sensitive detection of ROLP was developed and evaluated. This method could detect phytoplasma-infected rice samples with a minimum concentration of $100 \mathrm{pg} / \mu \mathrm{l}$, which is sufficient for detection of rice plants and leafhopper vector samples.

Although ROLD is currently found in eastern and southeastern Asia, field investigation in this study and reports from $\mathrm{Li}$ et al. (2015) and He et al. (2016) indicate that ROLD is spreading rapidly in the southern China rice growing region. It is a potential threat to all rice-growing regions of the world. Therefore, special attention should be paid to the potential reemergence of ROLP in the coming years. The PCR method for ROLP detection established in this study will facilitate such efforts. In addition to ROLD, rice yellow stunt disease (RYSD), caused by rice yellow stunt virus or rice transitory yellowing virus, was also found in southern China, Japan, India, and other Asian countries (Chiu et al. 1965; Fan et al. 1965; Nasu et al. 1967; Jackson et al. 2005). The two diseases share similar symptoms. The detection system developed in this study can help to differentiate ROLD from RYSD, as rice yellow stunt virus has an RNA genome that shows as negative in PCR.

\section{Literature Cited}

Ahrens, U., and Seemüller, E. 1992. Detection of DNA of plant pathogenic mycoplasmalike organisms by a polymerase chain reaction that amplifies a sequence of the 16S rRNA gene. Phytopathology 82:828-832.

Chen, J. C., Liu, H. R., and Peng, Q. D. 2001. Rice orange leaf disease occurred in Luchuan County (in Chinese). Guangxi Plant Pro. 33.

Chiu, R. J., Lo, T. C., Pi, C. L., and Chen, M. H. 1965. Pages 1-18 in: Transitory yellowing of Rice and its transmission by the leafhopper Nephotettix apicalis (Motsch). Botanical Bulletin of Academia Sinica, Taipei.

Christensen, N. M., Nicolaisen, M., Hansen, M., and Schulz, A. 2004. Distribution of phytoplasmas in infected plants as revealed by real-time PCR and bioimaging. Mol. Plant-Microbe Interact. 17:1175-1184.

Demeuse, K. L., Grode, A. S., and Szendrei, Z. 2016. Comparing qPCR and nested PCR diagnostic methods for aster yellows phytoplasma in aster leafhoppers. Plant Dis. 100:2513-2519.

Fan, H., Zeng, D. S., Ye, B. J., and Lu, B. C. 1965. The preliminary investigation on rice yellow stunt disease in Guangdong. (in Chinese) Plant Prot. 3:143-145.
Firrao, G., Garcia-Chapa, M., and Marzachi, C. 2007. Phytoplasmas: genetics, diagnosis and relationships with the plant and insect host. Front BiosciLandmrk. 12:1353-1375.

Guevara-Hernandez, E., Arvizu-Flores, A. A., Lugo-Sanchez, M. E., VelazquezContreras, E. F., Castillo-Yañez, F. J., Brieba, L. G., and Sotelo-Mundo, R. R. 2015. A novel viral thymidylate kinase with dual kinase activity. J. Bioenerg. Biomembr. 47:431-440.

Gundersen, D. E., and Lee, I. M. 1996. Ultrasensitive detection of phytoplasmas by nested-PCR assays using two universal primer pairs. Phytopathol. Mediterr. 35: 144-151.

Harrison, N. A., Womack, M., and Carpio, M. L. 2002. Detection and characterization of a lethal yellowing (16SrIV) group phytoplasma in Canary Island date palms affected by lethal decline in Texas. Plant Dis. 86:676-681.

He, Y. G., Li, S., Hao, W. J., Zheng, J. J., Zhong, B. Y., and Zhou, G. H. 2016. Molecular detection of rice orange leaf disease and research on its occurrence and distribution in Southern China. (in Chinese) China Plant Prot. 36:9-21.

Hibino, H., Jonson, G. B., and Sta. Cruz, F. C. 1987. Association of mycoplasmalike organisms with rice orange leaf in the Philippines. Plant Dis. 71:792-794.

Hogenhout, S. A., Oshima, K., Ammar, E., Kakizawa, S., Kingdom, H. N., and Namba, S. 2008. Phytoplasmas: bacteria that manipulate plants and insects. Mol. Plant Pathol. 9:403-423.

Ito, K., and Akiyama, Y. 2005. Cellular functions, mechanism of action, and regulation of FtsH protease. Annu. Rev. Microbiol. 59:211-231.

Jackson, A. O., Dietzgen, R. G., Goodin, M. M., Bragg, J. N., and Deng, M. 2005 Biology of plant Rhabdoviruses. Annu. Rev. Phytopathol. 43:623-660.

Kakizawa, S., and Kamagata, Y. 2014. A multiplex-PCR method for strain identification and detailed phylogenetic analysis of AY-group phytoplasmas. Plant Dis. 98:299-305.

Langer, T. 2000. AAA proteases: cellular machines for degrading membrane proteins. Trends Biochem. Sci. 25:247-251.

Lee, I. M., Hammond, R. W., Davis, R. E., and Gundersen, D. E. 1993. Universal amplification and analysis of pathogen $16 \mathrm{~S}$ rDNA for classification and identification of mycoplasmalike organisms. Phytopathology 83:834-842.

Lee, M. E., Grau, C. R., Lukaesko, L. A., and Lee, I. M. 2002. Identification of aster yellows phytoplasmas in soybean in Wisconsin based on RFLP analysis of PCR-amplified products (16S rDNAs). Can. J. Plant Pathol. 24:125-130.

Lee, S., Augustin, S., Tatsuta, T., Gerdes, F., Langer, T., and Tsai, F. T. 2011 Electron cryomicroscopy structure of a membrane-anchored mitochondrial AAA protease. J. Biol. Chem. 286:4404-4411.

Li, S., Hao, W., Lu, G., Huang, J., Liu, C., and Zhou, G. 2015. Occurrence and identification of a new vector of rice orange leaf phytoplasma in South China. Plant Dis. 99:1483-1487.

Lin, Y. Q., Xie, L. H., and Zhu, Q. L. 1983. Study on rice orange leaf disease (in Chinses). J. Fujian Agric. Univ. 12:195-201.

Mahillon, J., and Chandler, M. 1998. Insertion sequences. Microbiol. Mol. Biol. Rev. 62:725-774.

Murray, M. G., and Thompson, W. F. 1980. Rapid isolation of high molecular weight plant DNA. Nucleic Acids Res. 8:4321-4326.

Nasu, S., Sugiura, M., Wakimoto, T., and Iida, T. 1967. On the etiologic agent of rice yellow dwarf. Ann. Phytopathol. Soc. 33:343-344.

Nejat, N., and Vadamalai, G. 2013. Diagnostic techniques for detection of phytoplasma diseases: past and present. J. Plant Dis. Prot. 120:16-25.

Obura, E., Masiga, D., Wachira, F., Gurja, B., and Khan, Z. R. 2011. Detection of phytoplasma by loop-mediated isothermal amplification of DNA (LAMP). J. Microbiol. Methods 84:312-316.

Ostermann, N., Schlichting, I., Brundiers, R., Konrad, M., Reinstein, J., Veit, T., Goody, R., and Lavie, A. 2000. Insights into the phosphoryl transfer mechanism of human thymidylate kinase gained from crystal structure of enzyme complexes along the reaction coordinate. Structure 8:629-642.

Saito, Y., Chaimongkol, U., Singh, K. G., and Hino, T. 1976. Mycoplasmalike bodies associated with rice orange leaf disease. Plant Dis. Rep. 60:649-651.

Saraste, M., Sibbald, P. R., and Wittinghofer, A. 1990. The P-loop-a common motif in ATP- and GTP-binding proteins. Trends Biochem. Sci. 15:430-434.

Shen, J. Y., Chen, Z. Y., and Peng, J. M. 1983. Further study of the rice orange leaf disease in Yunnan province: Electron mircoscopical observation pathogen. (in Chinese) Acta Phytopathol. Sin. 13:55-56.

Valarmathi, P., Rabindran, R., Velazhahan, R., Suresh, S., and Robin, S. 2013. First report of rice orange leaf disease phytoplasma (16 SrI) in rice (Oryza sativa) in India. Australas. Plant Dis. Notes 8:141-143.

Weintraub, P. G., and Beanland, L. 2006. Insect vectors of phytoplasmas. Annu. Rev. Entomol. 51:91-111.

Zhang, S. B., Luo, X. W., and Li, H. P. 2008. The establishment of PCR detection system of rice orange leaf disease. (in Chinese) Hua Nan Nong Ye Da Xue Xue Bao 29:28-31.

Zhang, S. G., Fan, H. Z., Xiao, H. G., Xie, S. D., Zhou, X. M., Cai, H. X., and Yang, Y. X. 1995. On the identification of rice orange leaf occurring in Guangdong Province. (in Chinese) Acta Phytopathol. Sin. 25:233-237. http:// zwblxb.magtech.com.cn/EN/abstract/abstract2305.shtml

Zheng, Z., Xu, M., Bao, M., Wu, F., Chen, J., and Deng, X. 2016. Unusual five copies and dual forms of $n r d \mathrm{~B}$ in 'Candidatus Liberibacter asiaticus': Biological implications and PCR detection application. Sci. Rep. 6:39020.

Zhu, Y. Z., He, Y. G., Zheng, Z., Chen, J. C., Wang, Z. Y., and Zhou, G. H. 2017. Draft genome sequence of rice orange leaf phytoplasma from Guangdong, China. Genome Announc. 5:e00430-17. 